\title{
The mass and energy balance of ice within the Eisriesenwelt cave, Austria
}

\author{
F. Obleitner ${ }^{1}$ and C. Spött ${ }^{2}$ \\ ${ }^{1}$ Institute of Meteorology and Geophysics, Innsbruck University, Austria \\ ${ }^{2}$ Institute of Geology and Paleontology, Innsbruck University, Austria
}

Received: 14 September 2010 - Published in The Cryosphere Discuss.: 23 September 2010

Revised: 5 February 2011 - Accepted: 15 March 2011 - Published: 23 March 2011

\begin{abstract}
Meteorological measurements were performed in a prominent ice cave (Eisriesenwelt, Austria) during a full annual cycle. The data show the basic features of a dynamically ventilated cave system with a well distinguished winter and summer regime.

The calculated energy balance of the cave ice is largely determined by the input of long-wave radiation originating at the host rock surface. On average the turbulent fluxes withdraw energy from the surface. This is more pronounced during winter due to enhanced circulation and lower humidity. During summer the driving gradients reverse sign and the associated fluxes provide energy for melt.

About $4 \mathrm{~cm}$ of ice were lost at the measurement site during a reference year. This was due to some sublimation during winter, while the major loss resulted from melt during summer. Small amounts of accumulation occurred during spring due to refreezing of seepage water.

These results are largely based on employing a numerical mass and energy balance model. Sensitivity studies prove reliability of the calculated energy balance regarding diverse measurement uncertainties and show that the annual mass balance of the ice strongly depends on cave air temperature during summer and the availability of seepage water in spring.
\end{abstract}

\section{Introduction}

Ice caves were defined as rock caves containing seasonal and perennial ice (Ford and Williams, 1989). Only few of them contain ice bodies in excess of $100000 \mathrm{~m}^{3}$ (Silvestru, 1999). Therefore cave ice cannot have the global relevance of other cryospheric components regarding e.g. climate-induced sea-

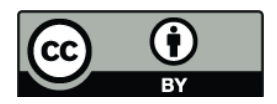

Correspondence to: F. Obleitner (friedrich.obleitner@uibk.ac.at) level changes. However, cave ice serves as a local resource (water, tourism), its degradation may destabilize underground and it preserves environmental information which remained largely unexplored so far.

Ice caves are known from all climate regions outside the tropics and are classified according to their geological origin (limestone, sea erosion, lava tubes) or regime of air flow (static or dynamically ventilated). Notably ice caves are also found in areas without permafrost i.e. at altitudes with an annual outside air temperature above $0^{\circ} \mathrm{C}$. Depending on the cave morphology this is due to accumulation of cold air or unidirectional advection of cold air into the cave during winter (Ford and Williams, 1989; Luetscher and Jeannin, 2004).

Several species of cave ice have been distinguished (Wigley and Brown, 1976; Ford and Williams, 1989; Luetscher et al., 2005) which are mainly determined by different formation processes (snow metamorphosis, ice intrusion/extrusion, refreeze of dripping and ponding water, hoar frost, inclusion in clastic sediments). Due to the unique environmental conditions (darkness, damped atmospheric signals, seepage water instead of atmospheric precipitation, no major mechanical stresses) cave ice is characterized by specific physical and chemical properties (Citterio et al., 2004; Hausmann and Behm, 2010; May et al., 2011). Therefore cave ice deposits are also considered as paleoclimate archives, which may be deciphered by stratigraphic or stable isotope analyses, dendrochronology or palynology. However, corresponding efforts were often hampered by discontinuous accumulation sequences and according dating problems (Yonge and MacDonald, 1999; Silvestru, 1992; Holmlund et al., 2005; Luetscher et al., 2007; Kern et al., 2009; Stoffel et al., 2009; May et al., 2011). The already dated cave ice records span the last millenium and thus provide valuable climatic information in regions where instrumental records or other proxies are missing (Stoffel et al., 2009; Holmlund et al., 2005).

Published by Copernicus Publications on behalf of the European Geosciences Union. 

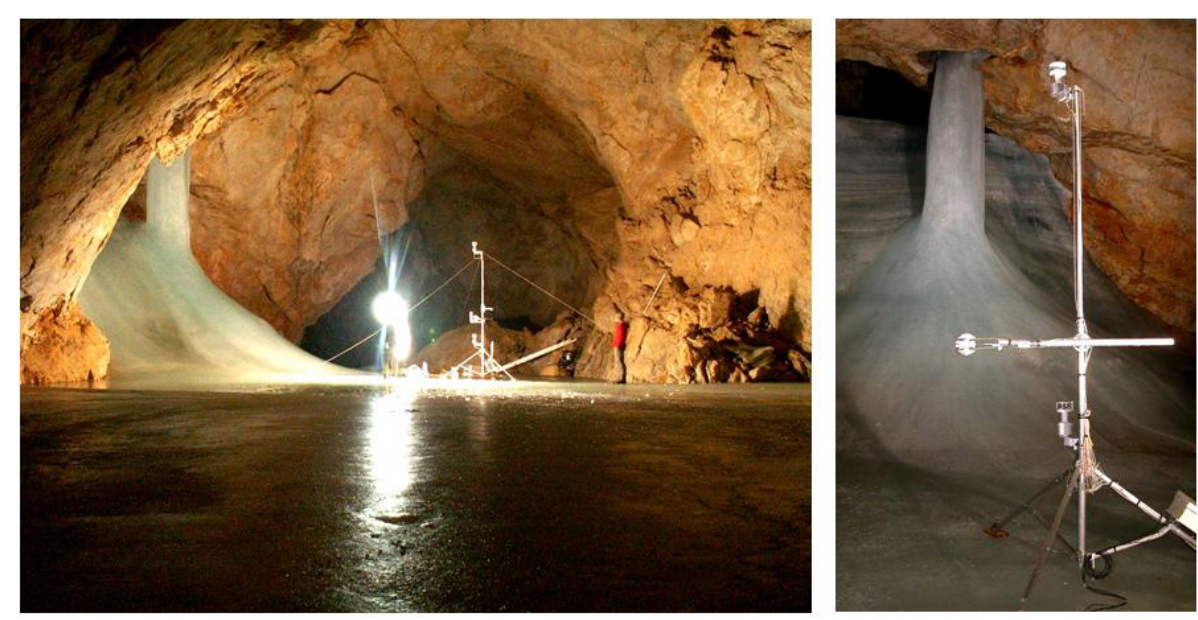

Fig. 1. View on the Eispalast measurement site (left) and on the meteorological instruments (right).

The sparse long-term observations indicate that the ice volume decreased in most caves during the past decades (Mavlyudov and Kadebskaya, 2004; Luetscher et al., 2005; Erhard and Spötl, 2010). However, such can hardly be interpreted without a thorough understanding of the complex processes within the soil-karst-cave system as a whole. For several ice caves relevant knowledge exists about the air circulation, but this is often based on rather inconsistent or shortterm observations as well (e.g. Saar, 1956; Pavuza and Mais, 1999; Mais, 1999). Even less is known about the energy and mass balance of cave ice deposits (Ohata et al., 1994a, b; Luetscher et al., 2008) indicating a lack on process-oriented investigations.

This paper deals with the processes related to the energy balance and the ice development at the distal end of the ice-bearing section of the Eisriesenwelt cave (hereafter abbreviated as ERW). ERW is located inside the Hochkogel Mountain at the western edge of Tennengebirge, Austria $\left(47^{\circ} 30^{\prime} \mathrm{N} ; 13^{\circ} 11^{\prime} \mathrm{E}\right)$. The cave has a total length of ca. $40 \mathrm{~km}$ with a lower entrance at $1641 \mathrm{~m}$ a.s.l. and probably several as yet unexplored upper entrances emerging at a karst plateau (ca. $2200 \mathrm{~m}$ a.s.1.). Thus, ERW is a dynamically ventilated cave whose detailed structure is not yet fully known. Perennial ice occurs within the first $700 \mathrm{~m}$ behind the lower entrance and the total ice volume was estimated to ca. $30000 \mathrm{~m}^{3}$ distributed across an area of ca. $10000 \mathrm{~m}^{2}$ (Silvestru, 1999). The basic features of air flow and ice conditions in this cave were already investigated by Hauser and Oedl (1923), Gressel (1955) and Saar (1957). Since about 1995 the show cave operators perform long-term temperature measurements at several sites along the ice-covered section of ERW. Unfortunately, these measurements are not yet carried out in a homogenous manner. Therefore, they are not suitable to evaluate eventual long-term trends, though providing extended insight to the thermal regime in the cave and its relationship to the outside conditions (Thaler, 2008).
Based on this background a multidisciplinary project was carried out yielding meteorological and glaciological data during a full annual cycle. Section 2 gives a description of the environment at the measurement site, which is followed by a documentation of instrumentation (Sect. 3) and the model used to calculate the energy and the mass balance of the ice (Sect. 4). The results are discussed in chapter 5 focusing on the meteorological and glaciological conditions at the measurement site, the calculated mass and energy balance and related sensitivity studies. This work is strongly linked to complementary investigations by Hausmann and Behm (2010), May et al. (2011) and Schöner et al. (2010).

\section{The site}

The measurements were performed at the distal end of the ice-covered section i.e. in the so-called Eispalast (hereafter abbreviated as EP). The name derives from a flat and homogeneous ice surface, which is located in a hall of ca. $50 \mathrm{~m}$ length and about $15 \mathrm{~m}$ height (Fig. 1). The frontal part of the hall is confined by two narrow, partly ice-covered and elevated openings, whereas the distal section develops into a wide, down-sloping and ice-free gallery. EP itself covers an area of about $1000 \mathrm{~m}^{2}$ and hosts ca. $3700 \mathrm{~m}^{3}$ of ice. This corresponds to about $1 / 10$ of the total ice volume in the cave. Ground penetrating radar and several drillings to the bedrock revealed a maximum ice thickness of $7 \mathrm{~m}$ (Behm and Hausmann, 2007; May et al., 2011) and indicate that the ice body sits in an asymmetrical bowl-like depression. The measured ice thickness at the location of our investigation is $3.03 \mathrm{~m}$ and the surface itself slightly slopes towards the distal margin. During cave visits we rarely observed dripping water from the ceiling of the hall. In spring 2009, however, we noted enhanced seepage water emerging from an ice column in the rear section of EP (Fig. 1, background), which will be referred to in a later context. 
ERW is a tourist attraction. However, the measurement site is situated beyond the visitor's path where temperature measurements do not indicate significant effects on the thermal regime at this location. Some disturbance of the natural ventilation regime may be expected due to the closure of a door at the main entrance during summer, which is negligible in context of this short-term study. This is due to the existence of a secondary entrance to the cave and the specific aerodynamic conditions at the measurement site (generally weak and divergent air flow in a large chamber). Notably, the door is open during winter when the cave environment is truly undisturbed.

\section{Measurements}

The data were collected by a specifically designed weather station measuring air temperature, humidity, wind speed and direction at two levels above the ice surface ( 1 and $4 \mathrm{~m}$ ). Further, we measured air pressure, down- and upwelling longwave radiation components and ice temperatures at 0.5 and $3 \mathrm{~m}$ below the ice surface. An ultrasonic ranger was installed to continuously monitor ice thickness changes. Instant values were stored onto a logger in $10 \mathrm{~min}$ intervals. Figure 1 shows the measurement site and the setup of the instruments.

The cave was visited nine times between May 2007 and October 2009 to maintain the sensors, to collect the data and to perform supporting measurements and observations. Thereby the mass balance of the ice was also monitored by stake readings. We also refer to data from the analysis of an ice core retrieved in June 2007 (density and grain structure; May et al., 2011). Further observations concern e.g. the surface conditions or the occurrence of seepage water.

Measurements in cave environments are challenging for e.g. limited accessibility of suitable sites and related problems to keep the instruments operative for longer periods. Further, the natural variability of the relevant environmental parameters is small and close to the detection limit of standard sensors. We therefore put essential effort into sensor calibration (laboratory calibration before and after field work, field intercomparison at the same level). On the other hand, cave measurements benefit e.g. from the lack of solar radiation which can not affect temperature or long-wave radiation sensors. Notable experiences are that ultra-sonic sensors proved reliable for measuring the mostly low wind speeds and the small surface height changes. On the other hand, attempts to measure the discharge of seepage water entering EP failed as well as one of the ice temperature sensors. The performance of the humidity and radiation sensors may have suffered from condensates or dust, which can hardly be quantified. More details about the sensors used are documented in Campbell Scientific, Inc. (2011a, b) or Gill Instruments Ltd. (2011) and specific issues are discussed in Sects. 5.2 and 5.4.1. Unfortunately, there was a gap in the data due to an intermittent failure of the logger in May
2009. Therefore, this study mostly refers to a reference period when uninterrupted data are available (December 2007 until November 2008).

\section{The model}

A one-dimensional numerical mass and energy balance model is used to simulate the seasonal evolution of the ice and its interaction with the atmosphere and the underlying rock (SNTHERM; Jordan, 1991). This model is adaptable to a wide range of environmental settings and is well established in snow and ice research (Rowe et al., 1995; Cline, 1997; Hardy et al., 1998; Gustafsson et al., 2001; Olefs and Obleitner, 2007; Fox et al., 2008). The ice and rock substrates are described in terms of nodal matrices (ice and dry solids) and void spaces (occupied by liquid water and saturated air). The model calculates vertical profiles of temperature, density, grain size, and liquid water content by solving the governing equations determining heat, mass, and momentum exchange within control volumes. Principally, the model solves the following energy balance equation:

$$
\begin{aligned}
\frac{d E}{d t} & =\int_{z=0}^{H}\left(\frac{d}{d t}\left(c_{p} \rho(z) T(z)\right)\right) d z+L_{\mathrm{V}} R_{\mathrm{F}, \mathrm{M}} \\
& =\mathrm{NR}+\mathrm{SHF}+\mathrm{LHF}+\mathrm{PHF}
\end{aligned}
$$

The left-hand terms represent the rate of the subsurface changes of internal energy $E$ due to associated changes in heat content and phase changes. Basically, this involves the processes related to heat and vapour diffusion, liquid water transport, and latent heat exchanges due to melt and freeze. Indirectly these terms also include the inherent uncertainties which will be addressed in Sect. 5.4.1. The right-hand terms represent the surface fluxes i.e. net radiation (NR), sensible heat flux (SHF), latent heat flux (LHF) and heat transfer by precipitation (PHF). In a cave environment NR is confined to the long-wave components and PHF considers the thermal effects related to seepage water. The surface fluxes are defined positive if providing mass or energy to a layer. The associated changes in mass $M$ (determined by ice thickness $H$ and density $\rho$ ) consider precipitation/seepage water $(P)$, evaporation/condensation or sublimation/deposition $(E / C)$ and runoff $\left(R_{\mathrm{M}}\right)$ :

$$
\frac{d M}{d t}=\int_{z=0}^{H}\left(\frac{d}{d t}(\rho(z))\right) d z \approx \rho \frac{d H}{d t}=P+E / C+R_{\mathrm{M}}
$$

A full documentation of the model parameterisations and the numerical methods is given in Jordan (1991). The model settings were adjusted to the specific conditions in a cave environment. Calculation of the turbulent fluxes is routinely based on Monin-Obukhov framework and a bulk-transfer parameterisation following Andreas and Murphy (1986). In our 


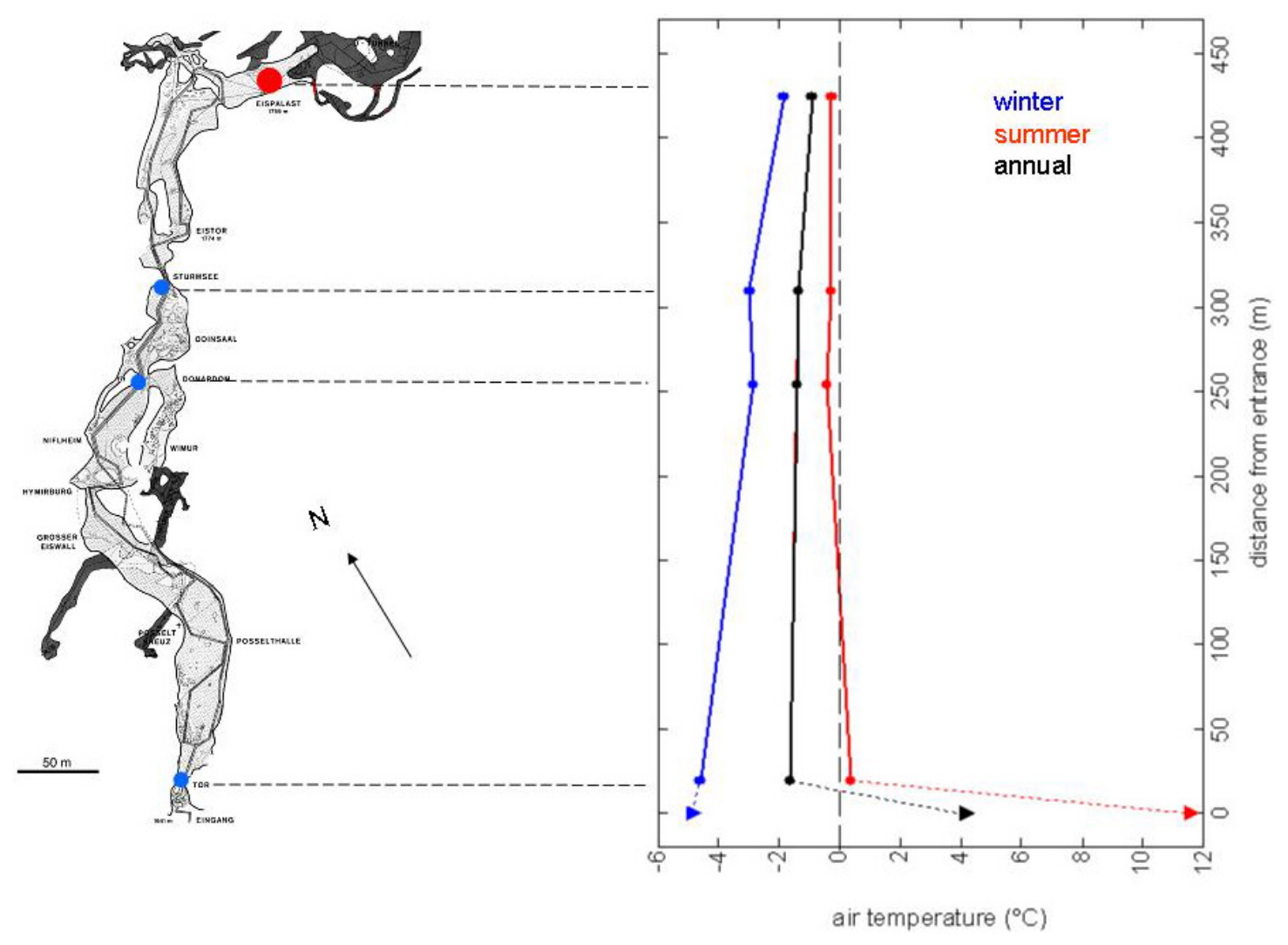

Fig. 2. Plan view of the ice-bearing part (light grey) of Eisriesenwelt (left) and seasonal average temperatures along this transect (1 December 2006 until 30 November 2007). Dots denote long-term temperature measurement sites within the cave, triangles denoting air temperature outside the cave (Feuerkogel, $1618 \mathrm{~m}$ ).

simulations the neutral exchange coefficients are calculated from a prescribed roughness parameter $(0.001 \mathrm{~m})$, stability corrections conform to Högström (1988) and scalar roughness lengths are calculated according to Andreas (1987). The rock substrate is represented as a soil species with appropriate characteristics (density and thermal conductivity corresponding to that of limestone, air and water transport prohibited). SNTHERM is a snow model and therefore allows for compaction of layers. As we deal only with ice the according routines were disabled, which is the only modification of the code.

The model domain is based on $4 \mathrm{~m}$ of rock material upon which development of the ice body is simulated in response to the atmospheric forcing. The initial ice thickness is $3.03 \mathrm{~m}$ corresponding to the measured depth from several drillings to the bed rock. The simulations consider 147 layers (rock and ice) and the resolution of the grid ranges between 1 and $0.001 \mathrm{~m}$, the latter being specified near the surface and at the rock-ice interface. To initialize the simulations, vertical profiles of temperature, bulk density and grain size were prescribed throughout the vertical domain. The density profile is based on analysis of an ice core drilled in June 2007 (May et al., 2011) and the temperature profile is derived from ice and rock temperature measurements. The latter were not yet available at the initialization time and taken horizontally at the level of the ice surface. Thus they may not be fully representative for the actual conditions at the base of the ice. It is to be noted, however, that the simulations were started at a time with minimum vertical temperature gradients (December) which is why the inherent uncertainties do not critically affect the simulations.

The simulations are forced by meteorological data from the lower measurement level $(1 \mathrm{~m})$. This is based on consideration of fetch criteria yielding $1-2 \mathrm{~m}$ as a critical level where the nearest local roughness changes may induce an internal boundary (Rao et al., 1974; Bradley, 1988). A corresponding sensitivity study proves that using data from the upper measurement level $(4 \mathrm{~m})$ does not critically change the flux calculations. This also indicates that there was no significant vertical flux divergence. The simulations were performed on an hourly basis and cover a full annual cycle (year 2008), which henceforth is considered as the reference period. 

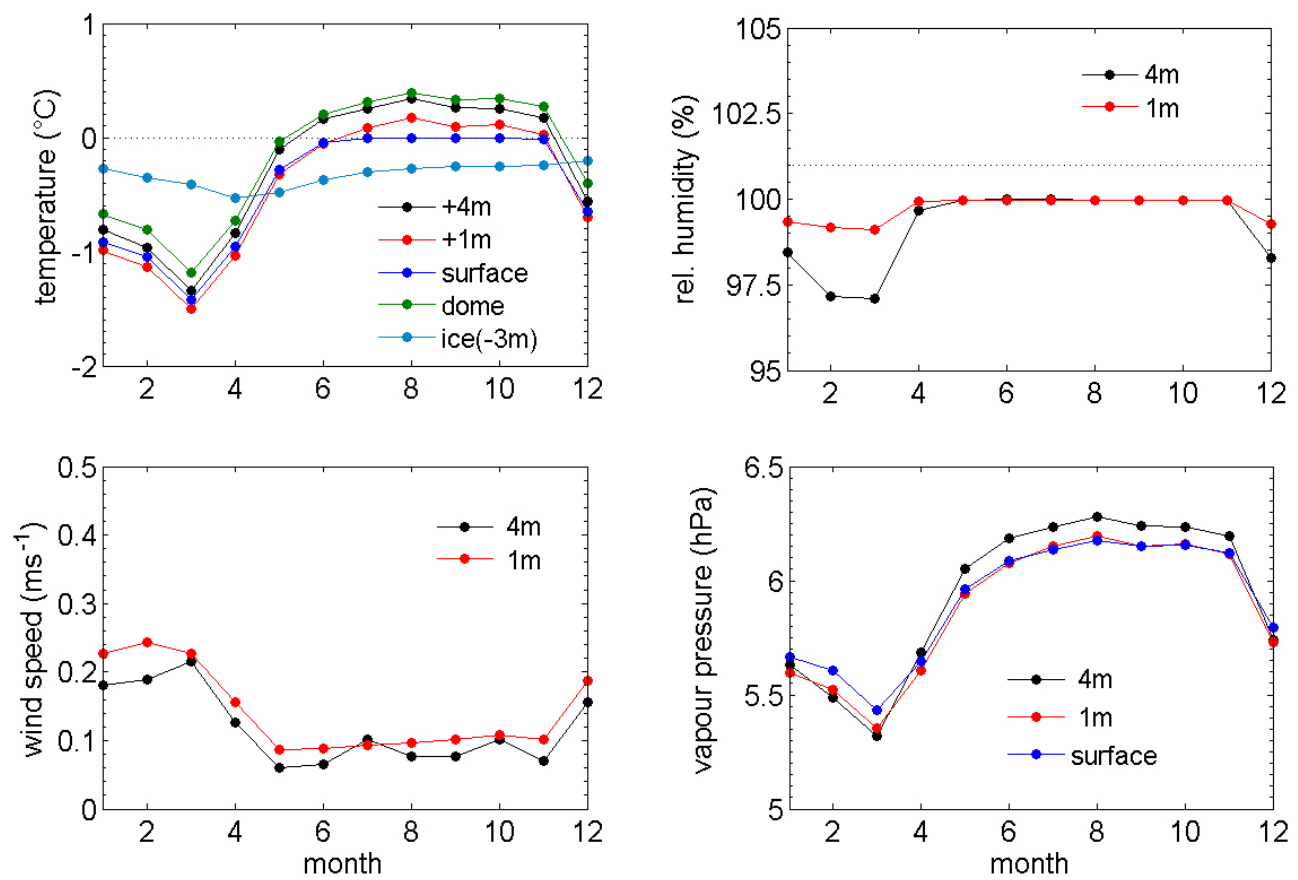

Fig. 3. Mean monthly values of measured temperatures (air, ice, rock) and humidity (upper panels) as well as of wind speed and vapour pressure (lower panels) at the EP measurement site.

\section{Results and discussion}

The following evaluation and discussion of the mass and energy balance of ice at EP is based on combining observational data and validated model output. We mainly consider a so-called reference run which is based on optimum data covering a full annual cycle (December 2007 until November 2008).

\subsection{Local meteorological and glaciological conditions}

The climatological conditions outside ERW are characterized by an average air temperature of $4.0^{\circ} \mathrm{C}$, an average precipitation of $1836 \mathrm{~mm}$ and a prevalence of north-westerly upper air winds. These data refer to the nearest climate station located at a distance of $50 \mathrm{~km}$ to the north and at about the same elevation as the cave entrance (Feuerkogel $1618 \mathrm{~m}$ a.s.l.; ZAMG, 2010). Evaluation of long-term temperature measurements within the cave show a progressive attenuation of the outside temperature fluctuations towards the cave interior (Fig. 2). Thus, the average seasonal temperature variation at EP is only about $1.5^{\circ} \mathrm{C}$ compared to $6^{\circ} \mathrm{C}$ at the entrance and $17^{\circ} \mathrm{C}$ in the outside atmosphere. These findings conform to the observations by Silvestru (1992), Thaler (2008) and Schöner et al. (2010).

The average conditions at the measurement site within the cave are characterized by an air temperature close to the melting point $\left(-0.45^{\circ} \mathrm{C}\right)$, relative humidity at saturation $(99.7 \%)$ and low wind speeds $\left(0.14 \mathrm{~m} \mathrm{~s}^{-1}\right)$. Figure 3 depicts more details in terms of monthly values at several measurement levels in the air and within the ice. Thus, air temperatures can be as low as $-1.5^{\circ} \mathrm{C}$ during winter, while being slightly positive from May to October $\left(+0.1^{\circ} \mathrm{C}\right)$. The extreme values range between $-1.8^{\circ} \mathrm{C}$ and $+0.3^{\circ} \mathrm{C}$. The air is significantly dryer during winter when wind speeds are higher (max. $0.6 \mathrm{~m} \mathrm{~s}^{-1}$ ) and the direction of the air flow features a clear bimodal frequency distribution with prevailing outflow during summer and inflow during winter (Fig. 4). Note that reversals in air flow occur quite often, especially during winter. The investigations by Oedl (1923), Saar (1957), Silvestru (1999), Thaler (2008) and Schöner et al. (2010) show that short-term reversals in air flow are mostly associated with major synoptic events.

This meteorological regime is rather typical for a dynamically ventilated cave system. Overall, the temperature, humidity and wind measurements reveal a distinct winter and summer regime terminating in May and November, respectively. This is corroborated by the seasonal pattern of the air flow (Fig. 4). Cold air is advected into the cave during winter and cools the host rock to about $-1.5^{\circ} \mathrm{C}$. Summer is characterized by a weak outflow of colder air from within the cave. Mean annual air temperature is slightly negative, thus just matching a basic condition for the existence of perennial ice. The subzero temperature regime is mainly supported by advection of cold air during periods of inflow during winter and associated sublimation of ice.

The vertical profiles of air temperature and humidity are subject to a distinct seasonal variability, too. During summer, 

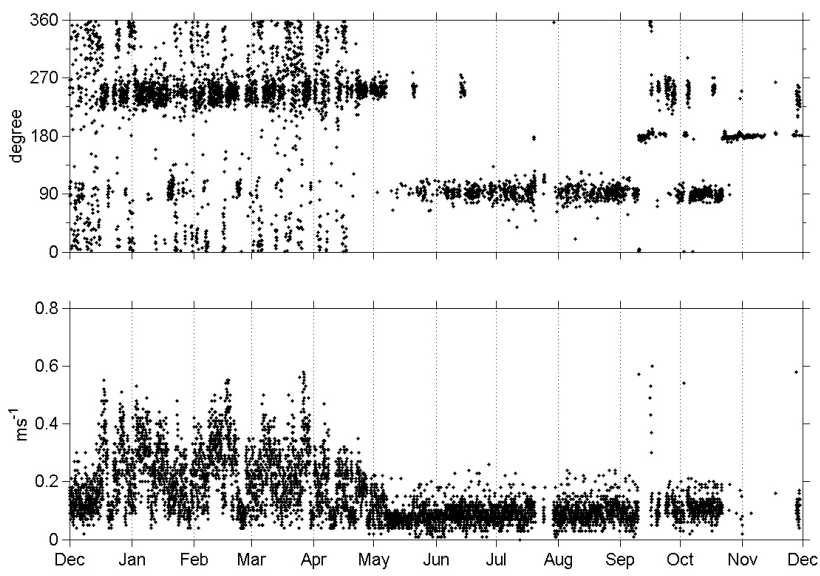

Fig. 4. Evolution of direction (upper panel) and velocitiy (lower panel) of the air flow at the measurements site. Inflow corresponds to westerly directions, outflow to easterlies.
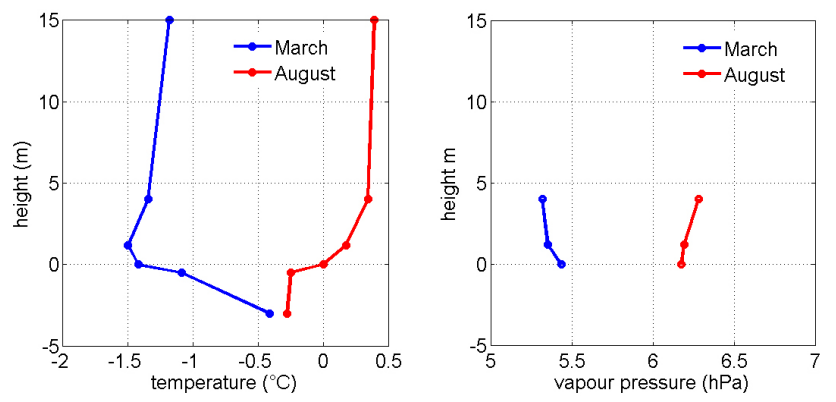

Fig. 5. Mean vertical profiles of temperature (air, ice, rock; left) and vapour pressure (right) measured at the EP measurement site during the warmest and coldest moth of the year.

we observe inversion conditions and an associated increase of humidity with height above ice surface (Fig. 5). Ice temperatures are at or close to the melting point and slightly decrease with depth. This conforms to the usual conditions above a melting glacier surface (Obleitner, 2000). These gradients reverse sign during winter which is mainly attributed to advection of cold and dry air from outside the cave. At this time of the year the deeper ice layers and the rock dome are warmer than the surface. This development has important consequences for the energy balance of the ice as will be shown later.

About $3.5 \mathrm{~cm}$ of ice were lost during the reference period (Table 1) and about $90 \%$ of this value was achieved during the melt period lasting from June until November. The remainder occurred during winter which is attributed to sublimation. There was no pronounced accumulation period observable during the reference period which will be discussed in the subsequent sections.
Table 1. Mean meteorological parameters and energy balance components (winter: 1 December 2007-30 May 2008, summer: 1 June 2008-30 November 2008).

\begin{tabular}{lrrr}
\hline & year & winter & summer \\
\hline air temperature $\left({ }^{\circ} \mathrm{C}\right)$ & -0.44 & -1.07 & 0.01 \\
rel. humidity $(\%)$ & 99.7 & 99.4 & 99.9 \\
wind speed $\left(\mathrm{m} \mathrm{s}^{-1}\right)$ & 0.14 & 0.21 & 0.09 \\
& & & +1.53 \\
net radiation $\left(\mathrm{NR}, \mathrm{Wm}^{-2}\right)$ & +1.00 & +0.47 & +0.04 \\
sensible heat $\left(\mathrm{SHF}, \mathrm{Wm}^{-2}\right)$ & -0.16 & -0.36 & +0.02 \\
latent heat $\left(\mathrm{LHF}, \mathrm{Wm}^{-2}\right)$ & -0.17 & -0.35 & +0.12 \\
energy change within rock & +0.07 & +0.25 & -0.12 \\
$\left(\mathrm{GHF}, \mathrm{Wm}^{-2}\right)$ & & & \\
energy change within ice & +0.74 & -0.08 & +1.47 \\
$\left(d E / d t, \mathrm{Wm}^{-2}\right)$ & & & \\
ice thickness change & -0.034 & -0.002 & -0.032 \\
$(d H / d t$, m) & & & \\
\hline
\end{tabular}

\subsection{Model validation}

The following investigation of the energy and mass budget of ice is strongly based on model output. Figure 6 demonstrates that the simulation does reproduce the seasonal evolution of ice thickness, which is considered as a measure of mass balance. The validating sonic data are representative for a surface area of $\sim 20 \mathrm{~cm}$ and have a nominal accuracy of $0.3 \mathrm{~cm}$ (Campbell Scientific, Inc., 2011b). However, effective accuracy of the latter is certainly better due to the small temperature variation and the absence of other disturbances in a cave environment. Stake measurements are sensitive to reading errors and the small-scale variability of the surface (Obleitner, 2000). Thus, the indicated increase of ice thickness in late summer 2008 must not interpreted as an accumulation event, but is attributed to a single disturbance of the stake imposing a systematic offset henceforth. As shortcomings of the simulations we note that sublimation is underestimated while ablation starts too late and the subsequent melt rate is overestimated. We could not yet identify the reason for these deficiencies. Fortunately, the individual effects cancel each other out on a seasonal time scale.

Surface temperature is considered as a key parameter reflecting the skill of the model to simulate the processes determining the energy balance. Comparison with measured values reveals that the seasonal development of surface temperature is captured at RMSE $=0.18^{\circ} \mathrm{C}$ and $r^{2}=0.95$ (Fig. 6, upper panel). The annual averages agree within $0.2^{\circ} \mathrm{C}$, which roughly corresponds to the effective accuracy of the associated long-wave radiation measurements (Obleitner and deWolde, 1999). The ice temperatures at 0.5 and $3 \mathrm{~m}$ below the surface are simulated with a similar skill (RMSE $=0.06 / 0.15^{\circ} \mathrm{C}$; Fig. 6 lower panels). The nominal accuracy of the validating sensors is specified as $\pm 0.2^{\circ} \mathrm{C}$ 

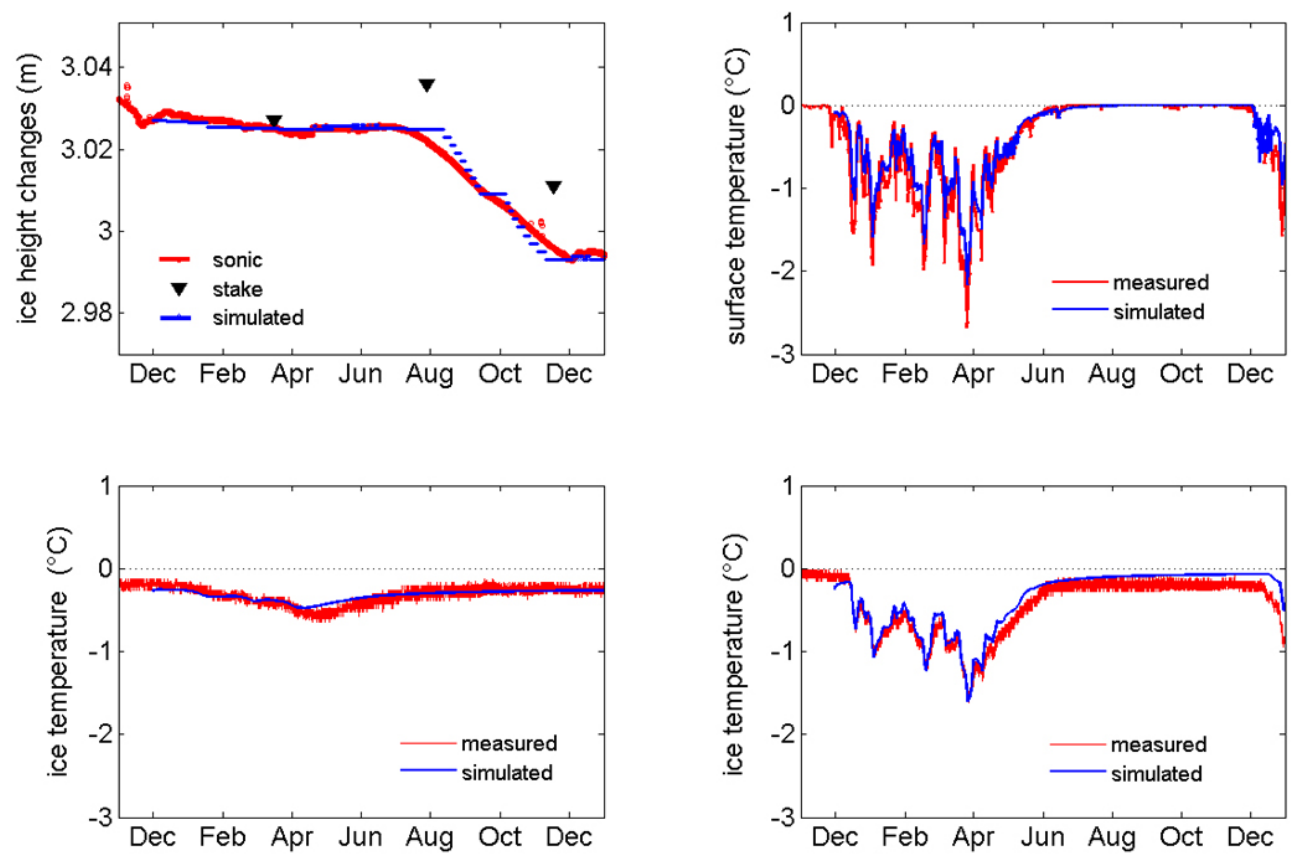

Fig. 6. The development of changes in ice thickness and surface temperature (upper panels) and of ice temperatures $3 \mathrm{~m}$ and $0.5 \mathrm{~m}$ below the ice surface (lower panels).

(Campbell Scientific, Inc., 2011b), which was improved to better than $\pm 0.1^{\circ} \mathrm{C}$ by laboratory recalibrations. The relatively noisy signal reflects the digitizing accuracy of the logger extension module measuring these sensors. The results further show a slight tendency to simulate too high values at the upper level and too low values at the lower level. In part this may be related to the inherent uncertainty in relating the exact position of the measurement levels to the model nodes.

\subsection{Energy and mass balance}

Table 1 points out the overall small magnitude of the calculated energy balance components compared to outside snow/ice environments (e.g. Greuell et al., 1997; Obleitner, 2000; Suter et al., 2004; Hock, 2005; Armstrong and Brun, 2008; Giesen et al., 2009). This is essentially true for net radiation which in a cave environment is constricted to the long-wave components. Nevertheless, long-wave radiation constitutes the most significant source of energy for the surface. This is related to the overall higher temperature of the cave ceiling compared to the ice surface (Fig. 3).

On average the turbulent fluxes both withdraw energy from the ice surface, essentially during winter (Table 1). Heat fluxes at the lower boundary play an alternating role. Driven by molecular heat conduction in response to the associated temperature gradients, the basal rock withdraws some heat during summer, while providing energy during winter. Heat transfer by seepage water is negligibly small and therefore not further considered. The annual net balance of the fluxes

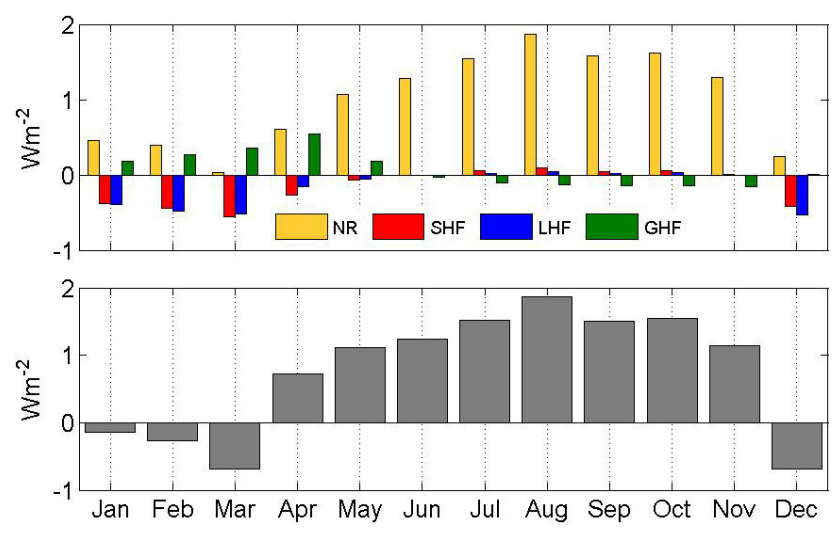

Fig. 7. Upper panel: mean monthly energy balance components NR (net radiation), SHF (sensible heat flux), LHF (latent heat flux), GHF (ground heat flux) and total energy balance $(d E / d t$; lower panel). Positive signs indicate a gain of energy at the surface.

at the upper and lower boundaries leaves energy to warm and melt the ice, which is corroborated by the observed decrease in ice thickness.

Figure 7 demonstrates the seasonal evolution of the energy balance in terms of monthly values. Net radiation is positive from April to November, which coincides with the period of positive rock temperatures (Fig. 3). Net radiation reaches a minimum in March when successive cold events penetrate far into the cave and cool the rock surfaces to about $-1.5^{\circ} \mathrm{C}$. The turbulent heat fluxes are positive from June to 
November, when air temperature and water vapour are higher than at the ice surface (Figs. 3 and 5). During winter the turbulent fluxes effectively withdraw energy from the surface, which contributes to an associated cooling and loss of ice due to sublimation. Molecular conduction within the rock underneath the ice is a heat sink during summer, while warming the ice at its base during the cold season. In response to the balance of these fluxes the ice experiences an energy deficit from December until March (Fig. 7, lower panel). However, this is overcompensated by excess energy during the period April until November which predetermines the positive sign of the annual energy balance.

Figure 8 demonstrates that the thermal regime within the ice is strongly determined by the atmospheric forcings at the surface. The cooling of the ice in winter is mainly associated with episodic cold waves which finally penetrate almost to the bottom of the ice. The warming phase during summer is of a more continuous nature and does not reach as far down. The associated melt water partly soaks the top few centimetres of the ice or runs off. This is corroborated by visual evidence during the cave visits. Notably, neither observations nor simulations indicate basal melt of ice under current conditions.

Putting these results in a broader context, we may compare them with accompanying investigations by Schöner et al. (2010) in the outer parts of ERW (Odinsaal and Posselthalle). They did not measure radiation or calculate the turbulent fluxes. However, their temperature and humidity data qualitatively confirm the prevalence of sublimation during winter and condensation during summer. The comparatively strong gradients $\left( \pm 2^{\circ} \mathrm{C}\right.$ and $\left.\pm 1 \mathrm{hPa}\right)$ and the higher wind speeds suggest that the magnitude of the turbulent fluxes must be larger in the outer cave sections. Further, there is evidence of a larger variability of the annual mass balance of ice in the outer parts of ERW $( \pm 15 \mathrm{~cm})$ compared to EP. This is mainly attributed to a correspondingly different meteorological regime (air temperature varying between +2 and $-12{ }^{\circ} \mathrm{C}$ ) and topographic effects (sloping surfaces, different water sources).

Evaluating historical photographs at EP, Spötl et al. (2008) document that $10-20 \mathrm{~cm}$ of ice was lost since the 1920s. Although this estimate refers to a location ca. $10 \mathrm{~m}$ west of our measurements site, it indicates that the currently observed retreat $\left(2-3 \mathrm{~cm} \mathrm{yr}^{-1}\right)$ is not fully representative on longer time scales. This is corroborated by ice core analysis revealing more positive mass balances prior to about 1930 (May et al., 2011). The latter conforms to similar evidences elsewhere in the Alps (Luetscher et al., 2005).

Ohata et al. (1994a, b) investigated the energy balance of perennial ice in a collapsed lava tube on Mt. Fuji (Japan). They considered monthly data during the period December 1985 to November 1986 and calculated the energy balance of the whole cave system. The turbulent fluxes were derived from temperature and humidity in and outside the cave, net radiation, ground heat flux and refreezing seep-

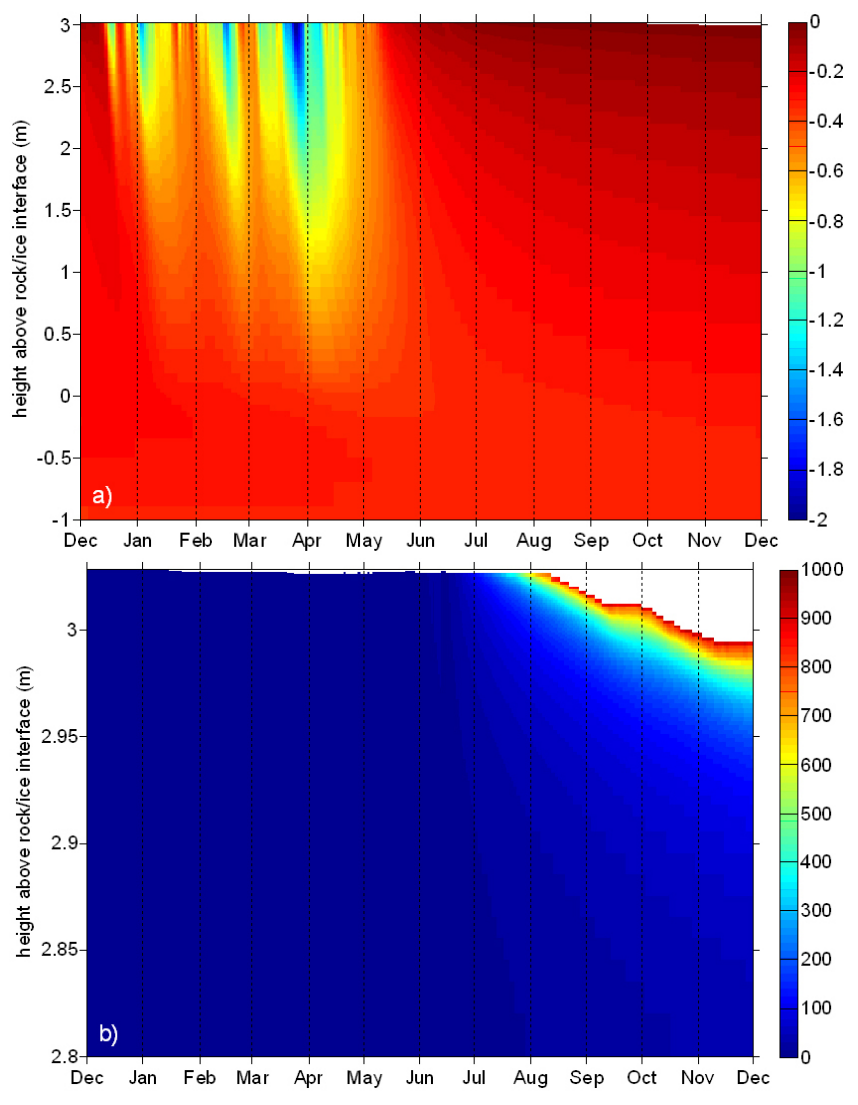

Fig. 8. Time-depth development of ice and rock temperatures within the model domain (upper panel) and liquid water content $\left(\mathrm{kg} \mathrm{m}^{-3}\right)$ in the top $20 \mathrm{~cm}$ (lower panel).

age water are contained in a residue. Conversion of the documented data to $\mathrm{Wm}^{-2}$ yields $\mathrm{NR}+\mathrm{GHF}+\mathrm{PHF}=2.0$, $\mathrm{SHF}=-1.6, \mathrm{LHF}=-0.8 \mathrm{Wm}^{-2}$. The authors also note a prevalence of sublimation during winter, a decrease of ice thickness $\left(-5 \mathrm{~cm} \mathrm{yr}^{-1}\right.$ from 1989 to 1992$)$ and a considerable variability in different parts of the cave.

Luetscher et al. (2008) investigated the energy and mass balance of perennial ice in Monlesi cave (Switzerland). This cave experiences similar outside temperatures as ERW and due to its sag-like topography there is weak oscillating air flow during summer and unidirectional ventilation during winter. The authors followed a similar approach as Ohata et al. (1994a), thus considering the energy balance of the whole cave system and data for a year with a negative mass balance ( $-10 \mathrm{~cm}$ during 2002/2003). Converting these data to $\mathrm{Wm}^{-2}$ yields $\mathrm{NR}+\mathrm{GHF}=1.0, \mathrm{SHF}=-0.5, \mathrm{LHF}=-0.4 \mathrm{Wm}^{-2}$. We are not aware of documented energy balance data from another ice cave. However, it is remarkable that at least for these three ice caves (Fuji, Monlesi and ERW) the magnitude and the sign of the calculated fluxes are remarkably consistent. 
Table 2. Mean energy balance components $\left(\mathrm{Wm}^{-2}\right)$ for different model settings and resulting changes in ice thickness $H$ (m). Abbreviations and key descriptions refer to the text, for run $\mathrm{mb}=0$ an amount of $0.05 \mathrm{~mm} \mathrm{~h}^{-1}$ seepage water was applied.

\begin{tabular}{llrrrrrr}
\hline & & $\mathrm{NR}$ & $\mathrm{SHF}$ & $\mathrm{LHF}$ & $\mathrm{GHF}$ & $d E / d t$ & $d H / d t$ \\
\hline $\mathrm{a})$ & reference & 1.00 & -0.16 & -0.17 & 0.07 & 0.74 & -0.034 \\
$\mathrm{~b})$ & $t+0.1$ & 0.91 & -0.09 & -0.12 & 0.06 & 0.76 & -0.039 \\
$\mathrm{c})$ & $t-0.1$ & 1.10 & -0.24 & -0.23 & 0.08 & 0.71 & -0.030 \\
$\mathrm{~d})$ & $\mathrm{rh}-1$ & 1.04 & -0.14 & -0.26 & 0.07 & 0.70 & -0.033 \\
$\mathrm{e})$ & $\mathrm{ws}+0.1$ & 1.02 & -0.18 & -0.17 & 0.07 & 0.74 & -0.035 \\
$\mathrm{f})$ & $\mathrm{l}+0.5$ & 1.37 & -0.20 & -0.21 & 0.05 & 1.00 & -0.063 \\
$\mathrm{~g})$ & $z 0=0.01 \mathrm{~m}$ & 1.02 & -0.17 & -0.18 & 0.07 & 0.74 & -0.035 \\
$\mathrm{~h})$ & without seepage water & 0.98 & -0.16 & -0.17 & 0.06 & 0.70 & -0.037 \\
i) & $t+1.5$ & 0.37 & 0.64 & 0.31 & -0.01 & 1.31 & -0.111 \\
j) & $t-0.5$ & 1.61 & -0.68 & -0.63 & 0.14 & 0.43 & -0.010 \\
$\mathrm{k})$ & $t+0.1$ and lw +0.50 & 1.28 & -0.13 & -0.16 & 0.04 & 1.03 & -0.070 \\
l) & $\mathrm{mb}=0$ & 1.00 & -0.17 & -0.17 & 0.07 & 0.72 & +0.001 \\
$\mathrm{~m})$ & $t+0.1$ and ws +0.1 & 0.98 & -0.13 & -0.15 & 0.06 & 0.76 & -0.039 \\
\hline
\end{tabular}

\subsection{Sensitivity studies}

A set of additional simulations was performed by systematically changing individual model input parameters. This kind of studies proved valuable to judge the potential influence of uncertainties regarding model input and parameterization (Obleitner and Lehning, 2004). Moreover, the potential response of the mass balance on assumed environmental changes can be addressed as well (Oerlemans and Reichert, 2000). Notably, the usually large uncertainties associated with albedo, turbulent fluxes or metamorphosis do not play a role in the context of cave ice simulations.

\subsubsection{Effects due to uncertainties of the input data}

Air temperature was measured with an accuracy of $\pm 0.1^{\circ} \mathrm{C}$. Table 2 a shows that this induces significant effects on calculated net radiation and turbulent fluxes compared to the reference run. A positive deviation reduces calculated net radiation, which via surface temperature is overcompensated by a smaller energy deficit by the turbulent heat fluxes (Table 2b). The net gain in energy induces enhanced melt and about $5 \mathrm{~mm}$ of ice are additionally lost. Consideration of a $-0.1^{\circ} \mathrm{C}$ deviation saves $4 \mathrm{~mm}$ of ice compared to the reference run (Table 2c). Introducing a $1 \%$ uncertainty in measured humidity mainly affects the latent heat exchange, but the net effect on the calculated mass balance is small due to the compensating response of net radiation and sensible heat flux (Table 2d). Changes in wind speed within the measurement accuracy lead to a slightly enhanced mass loss (Table 2e). Note that the indicated uncertainties correspond to the nominal accuracies of the used sensors (Gill Instruments Ltd., 2011), while their effective accuracy was certainly better due to recalibration efforts. Long-wave radiation was measured to within $\pm 0.5 \mathrm{Wm}^{-2}$ (Obleitner and deWolde, 1999). Port- ing this uncertainty into the simulation has a strong impact on the results and almost doubles calculated melt (Table 2f). Consideration of changes in parameterisation of the turbulent fluxes (roughness parameter set to $0.01 \mathrm{~m}$ instead of $0.001 \mathrm{~m}$ ) did not show significant effects on the results (Table $2 \mathrm{~g}$ ). This is mainly attributed to the overall small magnitude of the fluxes due to the low wind speeds and the small gradients of the driving variables, respectively.

Some input data could not be measured appropriately. This essentially concerns input of seepage water, where based on optimisation of the reference run an amount of $0.001 \mathrm{~mm} \mathrm{~h}^{-1}$ was prescribed whenever the rock ceiling temperature was positive and surface temperature was negative. The latter constraints were considered to represent conditions when seepage water is principally available and can refreeze on the still cold ice surface. A corresponding sensitivity study shows that this saves about $3 \mathrm{~mm}$ (Table $2 \mathrm{~h}$ ). Furthermore, there is an uncertainty regarding the input of the vertical temperature and density profiles at the start of the simulations. As mentioned this was based on ice temperature measurements at two depths only and the rock temperature was derived from near-surface, horizontally aligned borehole measurements and not at the base of the ice as desired. Density was derived from ice core analysis and bears an uncertainty in the order of $10 \%$ (May et al., 2011). The potential effects of these uncertainties on the simulated energy and mass budget are insignificant as is proven by corresponding sensitivity studies.

Overall, the sign and magnitude of the calculated fluxes proved robust with respect to conservative estimates of relevant measurement or parameterisation uncertainties. Judging by a $\pm 10 \%$ deviation compared to the reference run, the calculated mass balance is most sensitive with respect to proper treatment of long-wave radiation, air temperature and input 
of seepage water. This emphasizes that cave measurements require special effort regarding the choice of corresponding instruments.

\subsubsection{Potential climate impacts}

Sensitivity studies may also serve to investigate the energy and mass balance in response to potential changes in the environmental conditions. In this context, however, we do not refer to regional climate scenarios as e.g. put forward by Zhao (2007). Instead, we focus on a few extremes which are depicted in Table 2, too. Thus, we firstly consider a meteorological setting where air temperature remains positive throughout the year. An equivalent increase in air temperature $\left(+1.5^{\circ} \mathrm{C}\right.$, see also Fig. 3$)$ yields an enhanced loss of ice $\left(10 \mathrm{~cm} \mathrm{yr}^{-1}\right.$, Table 2i). The reversed sign of GHF indicates that in this case there would be some melt at the rock/ice interface, too. The contrasting assumption of a decrease in annual temperature $\left(-0.5^{\circ} \mathrm{C}\right)$ represents a regime where significant melt could not occur any more (Fig. 3). Corresponding simulations indicate that under such conditions there would still be a decrease in ice thickness $\left(1 \mathrm{~cm} \mathrm{yr}^{-1}\right)$ which is due to enhanced sublimation continuing throughout the year (Table $2 \mathrm{j}$ ).

Exemplifying the potential of feedback processes, we recall that an increase in outside air temperature will also change the rock dome temperature and correspondingly emitted long-wave radiation. The associated sensitivity study demonstrates that this positive feedback yields an enhanced effect compared to single parameter changes (Table 2k).

We further consider the response of the calculated annual mass balance of the ice at EP to monthly changes in temperature and input of seepage water. Increasing the temperature of individual months by $1{ }^{\circ} \mathrm{C}$ mainly affects the melt and results in more negative annual mass balances compared to the reference run (Fig. 9). This is due to enhanced energy input and a correspondingly longer melt period. The small saving effect during winter is due to less efficient sublimation. Refreezing seepage water generates less negative mass balances. To realistically constrain such effects we recall that the regional weather conditions are characterized by a precipitation maximum in June and a runoff maximum in May/June due to snow melt (ZAMG, 2010). Further, the percolation of meteoric water into the cave requires the existence of open conduits which can only occur at positive rock temperatures. To roughly account for these constraints, the respective sensitivity study considers input of seepage water only during periods when the temperature of the cave ceiling is positive and the ice surface temperature is negative. The results indicate that seepage water has a major mass saving effect during spring and to a minor extent in autumn (Fig. 9).

A further study aimed at encompassing environmental conditions that prohibit any loss of ice. It was already shown that this cannot be achieved by just reducing annual air temperatures (Table $2 \mathrm{j}$ ). This is due to ongoing sublimation

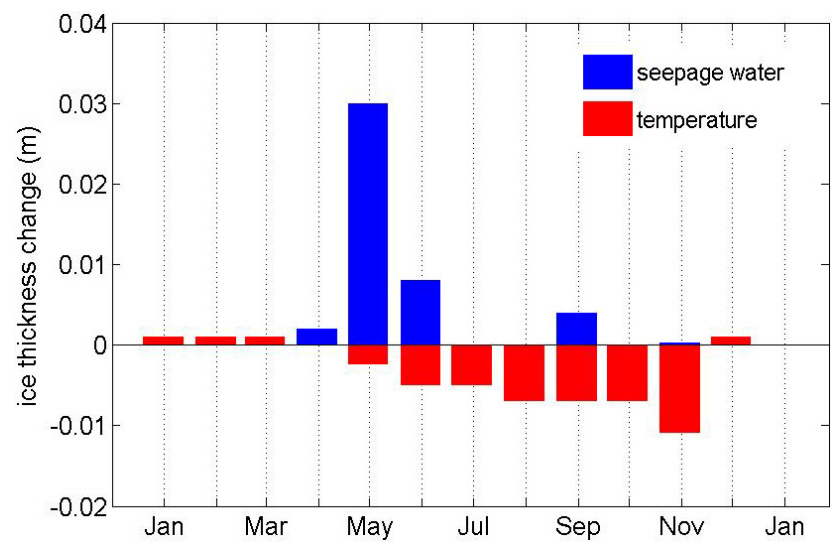

Fig. 9. Mean monthly sensitivity characteristics referring to increased temperature $\left(+1^{\circ} \mathrm{C}\right)$ and input of seepage water $\left(0.05 \mathrm{~mm} \mathrm{~h}^{-1}\right)$ in respective months. The effect on the mass balance is calculated in terms of monthly changes in ice thickness relative to the reference run.

which must be compensated by considerable input of seepage water that refreezes whenever the surface temperature is negative $\left(0.05 \mathrm{~mm} \mathrm{~h}^{-1}\right.$, Table 21$)$.

\subsubsection{Potential effects of the cave management}

ERW is subject to some cave management including closure of the entrance door during summer (May until October). The aim of this action is to prohibit the natural outflow of cold air during summer, which is thought to protect the ice. The actual effect, however, is unknown due to the lack of specific investigations. Employing our model for a corresponding study we assume that opening of the door during summer may increase air temperature by $0.1^{\circ} \mathrm{C}$ and increase wind speeds by $0.1 \mathrm{~m} \mathrm{~s}^{-1}$. The simulation results indicate that closing the door could thus save about $5 \mathrm{~mm} \mathrm{yr}^{-1}$ of ice (Table $2 \mathrm{~m}$ ). However this is likely overestimating the actual effect, because there is a secondary entrance which is not closed and provides natural ventilation all the year round.

Cave management may also involve changes of local water supply, which is not documented regarding the EP investigation site itself. However, Schöner et al. (2010) indicate that water management may affect the ice development in outer parts of ERW.

\subsection{Temporal and spatial representativness}

The representativness of the reference year 2008 may firstly be judged by climate data measured in the ERW environment. Relevant data (ZAMG, 2010) reveal that the years 2008 and 2009 were among the warmest during the last decade, the latter year being slightly colder $\left(4.4^{\circ} \mathrm{C}\right.$ vs. $4.2^{\circ} \mathrm{C}$ compared to the long-term average $3.6^{\circ} \mathrm{C}$ ). There was less precipitation during the colder year 2008 (2248 vs. 
$1777 \mathrm{~mm}$ ), which experienced more days with a closed snow pack on the other hand (202 vs. 182 days).

Figure 10 documents the evolution of mass balance for an extended period (June 2007 until September 2009). Note that this series covers the complete reference period (year 2008, dashed lines in Fig. 10) while the later series is interrupted due to a logger failure. However, the remaining data reveal a considerable interannual variability of the mass balance components. As regards ablation, there is only a small difference within the two years $(3.9 \mathrm{~cm}$ vs. $3.2 \mathrm{~cm})$ while accumulation strikingly differs (negligible in spring 2008 vs. $7.3 \mathrm{~cm}$ in spring 2009). This finding is supported by independent data (stake and sonic ranger) and is explained by a different availability of refreezing seepage water during the two years. This reasoning is based on observations of an ice column in the neighbourhood of the measurement site (Fig. 1, background) where an associated water conduit provided unusual amounts of water during spring 2009. This seepage water gradually spread over the rear parts of EP, thereby refreezing at the measurement site, too.

These observations are supported by corresponding model studies. Recall that a negligible input of seepage water is necessary to reproduce the measured mass balance in 2008 (reference run). As expected, the development during 2009 cannot be reproduced by a simulation without considerable input of seepage water in spring 2009. Forcing the model accordingly $\left(0.3 \mathrm{~mm} \mathrm{~h}^{-1}\right.$ of seepage water in May; $0.03 \mathrm{~mm} \mathrm{~h}^{-1}$ in June) indeed captures the observed development. These findings are relevant for the interpretation of an ice core recovered in the front part of EP (Spötl, 2008; May et al., 2011). Note however, that due to the adverse surface slope the drilling site is hardly affected by seepage water from the mentioned ice column.

\section{Conclusions and perspectives}

This work provides a process-oriented assessment of the energy and mass balance of cave ice based on observations and numerical modelling. The investigations were performed at the distal end of the ice-bearing section of Eisriesenwelt cave (Austria) and cover a full annual cycle.

The meteorological data exemplify the basic characteristics of a dynamically ventilated cave system. Compared to the outside atmospheric conditions, there is an overall small seasonal and interannual variability of air temperature, humidity and wind speed. Still there is a distinct winter and summer regime. Winter is characterized by prevailing inflow of cold air which by March cools the rock to subzero temperatures. There are frequent reversals of air flow which are related to major synoptic events. During summer there are slightly positive air temperatures and weak but persistent outflow from the cave interior. The mean annual air temperature is $-0.45^{\circ} \mathrm{C}$, thereby supporting the existence of peren-

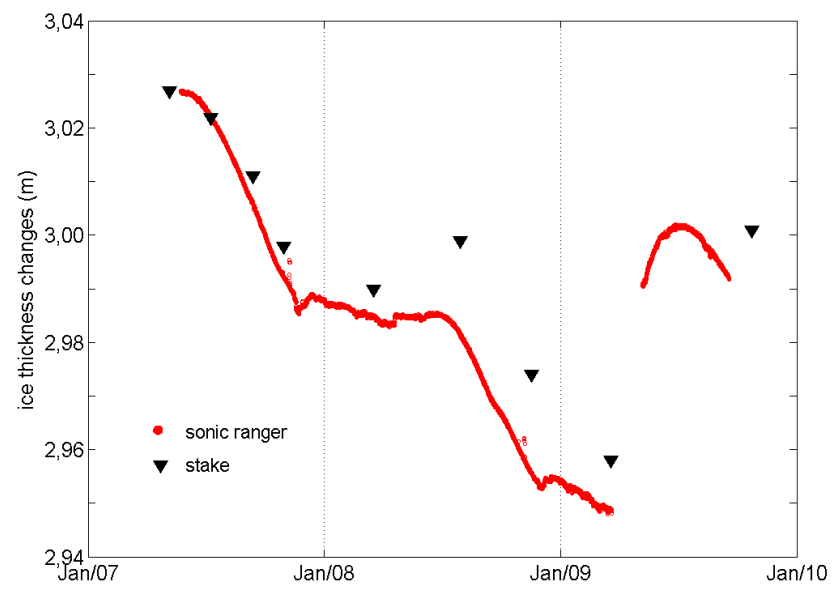

Fig. 10. Measured changes in ice thickness during two successive years indicating a strong influence of seepage water in spring 2009. Dashed lines mark the period of the reference run.

nial ice. This subzero temperature regime is mainly due to cold air advection during winter.

The vertical profiles of air temperature and humidity are subject to a distinct seasonal variability, too. During summer, we observed persistent inversion conditions and an increase of humidity with height above ice surface. During winter, the gradients reversed sign because of the advection of cold and dry air from outside the cave.

Ice thickness decreased by $3.5 \mathrm{~cm} \mathrm{yr}^{-1}$. The major loss resulted from summer melt and just about $10 \%$ was due to sublimation during winter. Small amounts of accumulation occurred due to refreezing of seepage water during spring.

The energy balance of the ice is largely determined by input of long-wave radiation originating at the cave ceiling. On average the turbulent fluxes withdraw energy from the surface. This is more pronounced during winter because of enhanced ventilation of the cave and lower humidity. During summer the turbulent fluxes provide small amounts of energy that enhance melt. Conductive heat exchange at the rock/ice interface withdraws energy during summer, while providing energy to the bottom ice layers during winter. These results are largely based on employing a one-dimensional numerical model. The simulations also show that the thermal regime within the ice is strongly affected by multiple cold waves during winter, which progress from the surface to about the ice-rock interface. The summer heat wave does not reach that far down. There are no signs of basal melt which is important for the existence of ice under current conditions.

Model sensitivity studies prove the reliability of the results regarding diverse measurement uncertainties. Moreover, the annual mass balance and its temporal and spatial variability are shown to strongly depend on late summer temperatures and the availability of seepage water in spring. 
Future studies may be directed right towards the latter topic employing e.g. tracer methods. There is also a basic need to develop specific instrumentation and long-term monitoring concepts that may be transferred to other caves, too. To start with, thermistor strings were installed at EP, aiming at long-term monitoring of the vertical temperature profiles in the air, as well as within the ice and the host rock, respectively. These investigations are supported by mass balance measurements using stakes. Accompanying studies revealed distinctly different atmospheric regimes in other parts of the cave and related impacts on the ice conditions. Further experiments and modelling efforts are needed to better understand the associated processes determining the existence and future development of ice deposits in different cave sections.

Acknowledgements. This work was funded by the Austrian Academy of Sciences (project AUSTRO*ICE*CAVES*2100) and Innsbruck University. Development of instrumentation was supported by Kroneis GmbH. and Sensalpin GmbH. Access to the cave and logistic support was generously provided by Eisriesenwelt $\mathrm{GmbH}$ and field work was assisted by several students of the Institute of Meteorology and Geophysics, Innsbruck University. We also acknowledge the reviews that helped to improve the manuscript.

Edited by: M. Luetscher

\section{References}

Andreas, E. L.: A theory for the scalar roughness and the scalar transfer coefficients over snow and sea ice, Bound.-Lay. Meteorol., 38, 159-184, 1987.

Andreas, E. L. and Murphy, B.: Bulk transfer coefficients for heat and momentum over leads and polynyas, J. Phys. Oceanogr., 16(11), 1875-1883, 1986.

Armstrong, L. and Brun, E. (Eds.): Snow and climate: Physical Processes, Surface Energy Exchange and Modeling, Cambridge University Press, 254 pp., 2008.

Behm, M. and Hausmann, H.: Eisdickenmessungen in alpinen Höhlen mit Georadar, Die Höhle, 58, 3-11, 2007.

Bradley, E. F.: A micrometeorological study of velocity profiles and surface drag in the region modified by change in surface roughness, Q. J. R. Meteor. Soc., 94, 361-379, 1988.

Campbell Scientific, Inc.: http://www.campbellsci.com/documents/ manuals/107.pdf, access: 22 March 2011a.

Campbell Scientific, Inc.: http://www.campbellsci.com/documents/ manuals/sr50a.pdf, access: 22 March 2011b.

Citterio, M., Turri, S., Bini, A., and Maggi, V.: Observed trends in the chemical composition. $\delta^{18} \mathrm{O}$ and crystal sizes vs. depth in the first ice core from the LoLc 1650 "Abisso sul margine dell'Alto Bregai" ice cave (Lecco, Italy), Theor. Appl. Karstol., 17, 45-50, 2004.

Cline, D. W.: Snow surface energy exchanges and snowmelt at a continental midlatitude Alpine site, Water Resour. Res., 33(4), 689-701, 1997.

Erhard, C. and Spötl, C.: Karst geology and cave fauna of Austria: a concise review, Int. J. Speleol., 39, 71-90, 2010.
Ford, D. and Williams, P.: Karst Geomorphology and Hydrology, London: Chapman and Hall, 601 pp., 1989.

Fox, A., Willis, I., and Arnold, N.: Modification and testing of a one-dimensional energy and mass balance model for supraglacial snowpacks, Hydrol. Process., 22, 3194-3209, 2008.

Giesen, R. H., Andreassen, L. M., van den Broeke, M. R., and Oerlemans, J.: Comparison of the meteorology and surface energy balance at Storbreen and Midtdalsbreen, two glaciers in southern Norway, The Cryosphere, 3, 57-74, doi:10.5194/tc-3-57-2009, 2009.

Gill Instruments Ltd.: http://www.gill.co.uk/data/datasheets/ MetPakIIWebDatasheet.pdf, access: 22 March 2011.

Gressel, W.: Zur Dynamik in alpinen Höhlen, Die Höhle, 6, 67-71, 1955.

Greuell, W., Knap, W. H., and Smeets, P. C.: Elevational changes in meteorological variables along a midlatitude glacier during summer, J. Geophys. Res., 102(D22), 25941-25954, 1997.

Gustafsson, D., Staehli, W., and Jansson, P.: The surface energy balance of a snow cover: comparing measurements to two different simulation models, Theor. Appl. Climatol., 70, 81-96, 2001.

Hardy, J. P., Davis, R., Jordan, R., Ni, W., and Woodcock, C. E.: Snow ablation modelling in a mature aspen stand of the boreal forest, Hydrol. Process., 12, 1763-1778, 1998.

Hauser, E. and Oedl, R.: Die große Eishöhle im Tennengebirge (Salzburg, Eisriesenwelt), V. Eisbildungen und meteorologische Beobachtungen, Speläologische Monogr., Wien, 6, 77-105, 1923.

Hausmann, H. and Behm, M.: Application of ground penetrating radar (GPR) in Alpine ice caves, The Cryosphere Discuss., 4, 1365-1389, doi:10.5194/tcd-4-1365-2010, 2010.

Hock, R.: Glacier melt: a review of processes and their modelling, Prog. Phys. Geog., 29(3), 362-391, 2005.

Högström, U.: Non-dimensional wind and temperature profiles in the atmospheric surface layer: a re-evaluation, Bound.-Lay. Meteorol., 42, 55-78, 1988.

Holmlund, P., Onac, B. P., Hansson, M., Holmgren, K., Morth, M., Nyman, M., and Persoiu, A.: Assessing the paleoclimate potential of cave glaciers: the example of the Scarisoara Ice Cave (Romania), Geogr. Ann. A., 87, 193-201, 2005.

Jordan, R.: A one-dimensional temperature model for a snow cover: technical documentation for SNTHERM.89, CRREL, Spec. Rep. 91-16, 49 pp., 1991.

Kern, Z., Molnár, M., Svingor, E., Pers, A., and Nagy, B.: Highresolution, well-preserved tritium record in the ice of Bortig Ice Cave, Bihor Mountains, Romania, The Holocene, 19, 729-736, 2009.

Luetscher, M. and Jeannin, P.: A process based classification of alpine ice caves, Theor. Appl. Karstol., 17, 5-10, 2004.

Luetscher, M., Jeannin, P., and Haeberli, W.: Ice caves as an indicator of winter climate evolution: A case study from the Jura Mountains, The Holocene, 15, 982-993, doi:10.1191/0959683605hl872ra, 2005.

Luetscher, M., Bolius, D., Schwikowski, M., Schotterer, U., and Smart, P.: Comparison of techniques for dating of subsurface ice from Monlesi ice cave, Switzerland, J. Glaciol., 53, 374-384, 2007.

Luetscher, M., Lismonde, B., and Jeannin, P. Y.: Heat exchanges in the heterothermic zone of a karst system: Monlesi cave, Swiss Jura Mountains, J. Geophys. Res., 113, F02025, 
doi:10.1029/2007JF000892, 2008.

Mais, K.: Untersuchungen des Höhlenklimas in der DachsteinRieseneishöhle von 1910-1962, Die Höhle, 50, 118-140, 1999.

May, B., Spötl, C., Wagenbach, D., Dublyansky, Y., and Liebl, J.: First investigations of an ice core from Eisriesenwelt cave (Austria), The Cryosphere, 5, 81-93, doi:10.5194/tc-5-81-2011, 2011.

Mavlyudov, B. R. and Kadebskaya, O. I.: About degradation of glaciation in Kungur cave and possible ways of ist restoration, in: Abstracts of the 1st International Workshop on Ice Caves, Capus, Romania, 2004.

Obleitner, F.: The energy balance of snow and ice at Breidamerkurjökull, Vatnajökull, Iceland, Bound.-Lay. Meteorol., 97, 385-410, 2000.

Obleitner, F. and deWolde, J.: On intercomparison of instruments used within the Vatnajökull glacio-meteorological experiment, Iceland, Bound.-Lay. Meteorol., 92, 27-37, 1999.

Obleitner, F. and Lehning, M.: Measurement and simulation of snow and superimposed ice at the Kongsvegen glacier, Svalbard (Spitzbergen), J. Geophys. Res., 19, 1-12, D04106, doi:10.1029/2003JD003945, 2004.

Oedl, R.: Über Höhlenmeteorologie mit besonderer Rücksicht auf die große Eishöhle im Tennengebirge, Meteorol. Z., 40, 33-37, 1923.

Oerlemans, J. and Reichert, B.: Relating glacier mass balance to meteorological data by using a seasonal sensitivity characteristic, J. Glaciol., 46, 1521-1526, 2000.

Ohata, T., Furukawa, T., and Higuchi, K.: Glacioclimatological study of perennial ice in the Fuji Ice Cave, Japan, Part 1, Seasonal variation and mechanism of maintenance, Arctic Alpine Res., 26, 227-237, 1994a.

Ohata, T., Furukawa, T., and Higuchi, K.: Glacioclimatological study of perennial ice in the Fuji Ice Cave, Japan, Part 2, Interannual variation and relation to climate, Arctic Alpine Res., 26, 238-244, 1994b.

Olefs, M. and Obleitner, F.: Numerical simulations on artificial reduction of snow and ice ablation, Water Resour. Res., 43, W06405, doi:10.1029/2006WR005065, 2007.

Pavuza, R. and Mais, K.: Aktuelle höhlenklimatische Aspekte der Dachstein-Rieseneishöhle, Die Höhle, 50, 126-140, 1999.

Rao, K., Wyngaard, J., and Coté, O.: The structure of the twodimensional internal boundary layer over a sudden change of surface roughness, J. Atmos. Sci., 31, 738-746, 1974.

Rowe, C. M., Kuiven, K. C., and Jordan, R.: Simulation of summer snowmelt on the Greenland ice sheet using a one-dimensional model, J. Geophys. Res., 100, 16265-16273, 1995.
Saar, R.: Eishöhlen, ein meteorologisch-geophysikalisches Phänomen, Untersuchungen an der Rieseneishöhle (R.E.H.) im Dachstein, Oberösterreich, Geogr. Ann. A., 38, 1-63, 1956.

Saar, R.: Zur Frage des Einflusses der Grosswetterlage auf die Dynamik der Wetterhöhlen, Die Höhle, 8, 33-44, 1957.

Schöner, W., Weyss, G., and Mursch-Radlgruber, E.: Linkage of cave-ice changes to weather patterns inside and outside the cave Eisriesenwelt (Tennengebirge, Austria), The Cryosphere Discuss., 4, 1709-1740, doi:10.5194/tcd-4-1709-2010, 2010.

Silvestru, E.: Ultrasonic investigations on the underground fossil glacier in the cave Ghearul de la Scărişoara (Romania), Trav. Inst. Spéléo. E. Racovitza, 31, 151-154, 1992.

Silvestru, E.: Perennial ice in caves in temperate climate and its significance, Theor. Appl. Karstol., 11-12, 83-94, 1999.

Spötl, C.: Kryogene Karbonate im Höhleneis der Eisriesenwelt, Die Höhle, 59, 26-36, 2008.

Spötl, C., Wagenbach, D., Obleitner, F., May, B., Behm, M., Schöner, W., Hausmann, H., Pavuza, R., Thaler, K., and Schöner, M.: AUSTRO_ICE_CAVES-2010, Unpublished final project report, 51 pp., 2008.

Stoffel, M., Luetscher, M., Bollschweiler, M., and Schlatter, F.: Evidence of NAO control on subsurface ice accumulation in a 1200 -yr old cave-ice sequence, St. Livres ice cave, Switzerland, Quaternary Res., 72, 16-26, 2009.

Suter, S., Hoelzle, M., and Ohmura, A.: Energy balance at a cold Alpine firn saddle, Seserjoch, Monte Rosa, Int. J. Climatol., 24, 1423-1442, 2004

Thaler, K.: Analyse der Temperaturverhältnisse in der Eisriesenwelt-Höhle im Tennengebirge anhand einer 12jährigen Messreihe, diploma thesis, University of Innsbruck, 93 pp., 2008.

Wigley, T. and Brown, M.: The glaciers of caves, in: The Science of Speleology, edited by: Ford, T. and Cullingford, C., London, Academic Press, 319-358, 1976.

Yonge, C. J. and MacDonald, W. D.: The potential of perennial cave ice in isotope paleoclimatology, Boreas, 28(3), 357-362, 1999.

ZAMG: http://www.zamg.ac.at/fix/klima/jb2008/index_e.html, 2010.

Zhao, C.: Global Climate Projections, in: Climate Change 2007: The Physical Science Basis. Contribution of Working Group I to the Fourth Assessment Report of the Intergovernmental Panel on Climate Change, edited by: Solomon, S., Qin, D., Manning, M., Chen, Z., Marquis, M., Averyt, K. B., Tignor, M., and Miller, H. L., Cambridge University Press, Cambridge, United Kingdom and New York, NY, USA, 2007. 